\title{
CSAG3 wt Allele
}

National Cancer Institute

\section{Source}

National Cancer Institute. CSAG3 wt Allele. NCI Thesaurus. Code C81904.

Human CSAG3 wild-type allele is located in the vicinity of Xq28 and is approximately $6 \mathrm{~kb}$ in length. This allele, which encodes chondrosarcoma-associated gene 2/3A protein, is involved in drug resistance. Aberrant expression of this gene is observed in many tumor cell lines. 